\title{
Palaeoenvironmental analysis of the Aragonian (middle Miocene) mammalian faunas from the Madrid Basin based on body-size structure
}

\author{
B.A. García Yelo ${ }^{1,2, *}$, A.R. Gómez Cano 2, 3, J.L. Cantalapiedra1, 2, G.M. Alcalde ${ }^{1}$, O. Sanisidro ${ }^{1}$, A. \\ Oliver $^{1}$, V. Hernández-Ballarín ${ }^{1}$, P. López-Guerrero ${ }^{2,3}$, S. Fraile ${ }^{1}$, M. Hernández Fernández ${ }^{2,3}$ \\ ${ }^{1}$ Departamento de Paleobiología. Museo Nacional de Ciencias Naturales (CSIC), C. José Gutiérrez Abascal 2, 28006 Madrid, Spain \\ ${ }^{2}$ Departamento de Paleontología, Facultad de Ciencias Geológicas (UCM), José Antonio Novais 2, 28040 Madrid, Spain \\ ${ }^{3}$ Instituto de Geociencias (UCM, CSIC), José Antonio Novais 2, 28040, Madrid, Spain.
}

e-mail addresses: bagy@mncn.csic.es (B.A.G.Y., *Correspondingauthor); jlopezcant@gmail.com (J.L.C.); paleogem@gmail.com (G.M.A.); osanisidro@mncn. csic.es (O.S.); mcnao831@mncn.csic.es (A.O); verohernandez@mncn.csic.es (V.H.-B.); susana.fraile@hotmail.com (S.F.); argomez@geo.ucm.es (A.R.G.C.); palomalopez@geo.ucm.es (P.L.-G.); hdezfdez@geo.ucm.es (M.H.F.)

Received: 24 October 2013 / Accepted: 3 December 2013 / Available online: 25 February 2014

\begin{abstract}
As a consequence of the growth of the Antarctic ice-sheet during the middle Miocene, a global decrease of temperatures and an associated increase in aridity provoked several environmental changes all around the world. Such environmental variations can be detected in the continental record of the mammalian prey community structure using a synecological approach. Because of the good quality of its faunas, the rich Aragonian vertebrate fossil record from the Madrid Basin (Spain) appears as a good candidate to explore these environmental changes. In order to analyse the climatic evolution of the Iberian Peninsula associated to the Global Cooling Event, two classic palaeosynecological methodologies (cenograms and body size diversity), based on body-size community structure, were applied to 6 fossil sites from the Madrid Basin, ranging over 2 million years (15.5 - 13.5 Ma). To establish a comparative framework, we used the ecological faunal data from 100 modern localities uniformly distributed all around the world. Our palaeoenvironmental inference is based on multivariate discriminant analysis of the dataset containing both modern and fossil mammals. Finally, we can conclude that the Aragonian mammalian assemblage from the Madrid Basin showed a predominance of semiarid environments with pulses of higher aridity in biozones Dc, E and F associated with the Global Cooling Event of the middle Miocene.
\end{abstract}

Keywords: Aragonian, Prey Mammal Community Structure, Madrid Basin, Body-size spectra, Cenograms, Climate

\section{Resumen}

Como consecuencia del crecimiento del casquete polar Antártico, durante el Mioceno medio, se produjo un descenso global de la temperatura asociado a un aumento de la aridez. Este tipo de cambios ambientales pueden ser detectados en el registro continental, siguiendo un modelo sinecológico para analizar la estructura de las comunidades de las faunas de mamíferos herbívoros. Debido a la calidad de sus faunas, el registro fósil de las faunas de vertebrados del Aragoniense de la Cuenca de Madrid se antoja como un buen candidato para explorar estos patrones de cambio ambiental. Con el objetivo de analizar la evolución climática de la Península Ibérica asociada al evento de enfriamiento global durante este lapso temporal, dos metodologías paleosinecológicas clásicas (cenogramas y espectros de diversidad de tamaño corporal), basadas en la estructura de tamaños corporales de las comunidades de mamíferos, han sido aplicadas a la fauna de herbívoros fósiles presente en seis yacimientos de la Cuenca de Madrid, abarcando aproximadamente 2 millones de años (15.5 - $13.5 \mathrm{Ma}$ ). Se ha establecido un marco comparativo usando los datos ecológicos de la fauna de mamíferos presente en 100 localidades uniformemente distribuidas por todo el planeta. Esta inferencia paleoambiental está basada en la aplicación de análisis discriminante multivariante sobre el conjunto de datos de las faunas actuales y fósiles. Finalmente, las faunas de mamíferos del Aragoniense de la Comunidad de Madrid mostraron una predominancia de ambientes semiáridos con varios pulsos de mayor aridez en las biozonas Dc, E y F asociados al evento de enfriamiento global del Mioceno medio. 


\section{Introduction}

The Miocene Climatic Optimum (MCO), recorded $\sim 17$ to $15 \mathrm{Ma}$, represents one of the warmest periods of the last 30 million years (Zachos et al., 2001; Shevenell et al. 2004). It lasted until $14 \mathrm{Ma}$, when a climatic change from warm and humid conditions to a more arid and cooler environment took place as a consequence of the growth of the Antarctic icesheet. This climatic change, known as Global Cooling Event, has been recorded in both marine and continental records using sedimentary and faunal data (e.g. Kennett and Barker, 1990; Böhme, 2003; Zachos et al., 2001; Lewis et al. 2008). Clift (2010) related changes in erosion rates across Eurasia, North America and Africa with climatic fluctuations during the last $33 \mathrm{Ma}$, peaking around $16 \mathrm{Ma}$ ago. In Hauptvogel and Passchier's (2012) study, the analysis of heavy mineral composition of one drill core allowed them to define the Antarctic ice dynamics related to the climatic change during the early to middle Miocene (17 to $14 \mathrm{Ma}$ ). Faunal studies based on the evolution of hypsodonty in large herbivorous mammals from Asia (Liu et al., 2008), and modifications on ecophysiological structure of herpetological assemblages (Böhme et al., 2010), also detected a significant increase in aridity related to the Global Cooling Event. Finally, Larsson et al. (2011) investigated palynological composition of sediments from the Danish coast (lower to upper Miocene, 19 to $8 \mathrm{Ma}$ ) that also showed major climatic shifts during the Miocene.

As homeotherms and habitat-sensitive animals, mammals are one of the best proxies to detect these climatic changes in the continental record (Vrba, 1992; Barnosky, 2001). Variations in their ecological characteristics can be used to detect environmental constraints. In fact, shifts in their feeding habits (Domingo et al., 2009, 2012; De Miguel et al., 2011; Zhou et al., 2011), locomotor adaptations (Lewis, 1997; Samuels and Van Valkenburgh, 2009; Meloro, 2011), and body size or morphology (Legendre, 1986; Shepherd, 1998; Rodríguez, 2001) have been found to correlate to climate and ecological dynamics. Besides, body size has been traditionally related to climate via Bergmann's and Allen's rules (Bergmann, 1847; Allen, 1877), which stated a latitudinal variation pattern in mammal (and birds) body size and shape. These rules have been almost equally accepted (Mayr, 1956, 1963; Ashton et al., 2000; Ashton, 2001; Meiri and Dayan, 2003) and rejected (Scholander, 1954; McNab, 1971; Fuentes and Jaksić, 1979; Meiri et al., 2007). Although the original ideas expressed by Bergmann and Allen are not exactly supported, a relationship between climatic proxies and mammal body size can be established (Boyce, 1978; Wigginton and Dobson, 1999; YomTov and Geffen, 2006) and confirms the value of this feature in climate inference.

However, the relationship between mammalian ecology and climate is not only reflected at the individual level, but also in the structure of the communities. During the last decades, the palaeoclimate from different periods and regions has been established based on the body size community structure of mammal fossils (Legendre, 1986, 1989; Montuire, 1999; Rodríguez, 1999; Croft, 2001; Storer, 2003; Hernández Fernández et al., 2006a; Palombo and Giovinazzo, 2006; Tougard and Montuire, 2006; Costeur et al., 2007; Travouillon and Legendre, 2009; Travouillon et al., 2009).

The well-studied mammalian groups from the Iberian Peninsula (Meulen and Daams, 1992; Fraile et al., 2000; Hernández Fernández et al., 2003, 2006a; Domingo et al., 2009, 2012), among the richest of the Neogene (Daams et al., 1977; Alba et al., 2001), represent a good opportunity to analyse ecomorphological aspects of fossil assemblages and their relationship to the climatic change that took place $14 \mathrm{Ma}$ ago. Particularly, the evolution of the body size community structure of the middle Miocene prey fauna from the Madrid Basin allows us to explore the connection between ecological community dynamics and macroenvironmental changes.

The Madrid Basin, originated by an endorheic lacustrine system (Calvo, 2000), is filled by detrital, evaporitic and carbonatic sediments. The age of the whole section ranges between 20 to $5.4 \mathrm{Ma}$, with three different lithostratigraphic units from the Madrid Basin defined (Alberdi, 1985; Calvo, 1989; Calvo et al., 1993): the Lower Unit (Ramblian to middle Aragonian), the Middle Unit (middle Aragonian to Vallesian) and the Upper Unit (Vallesian to Turolian). Several similar changes between humid and arid conditions have been also detected in this region for this short time in previous studies about the modifications in mammal body size community structure (Hernández Fernández et al., 2006a), the dietary evolution of herbivores (Domingo et al., 2009, 2012) or by changes in the mineral composition of the sediments present in the Somosaguas fossil site (Carrasco et al., 2008).

The aim of this research is to detect changes in the prey's community structure through time and to relate these changes to several major climatic fluctuations that took place during the middle Aragonian (middle Miocene). Thus, in order to evaluate the climatic evolution of the Madrid Basin before and after the middle Miocene Global Cooling Event, we applied two classic palaeo-synecological methodologies traditionally used for this purpose; cenograms (developed by Valverde (1964) and palaeoenvironmentally applied by Legendre in 1986 and 1989) and body size diversity (developed by Fleming (1973) and applied to the fossil record by Andrews et al., 1979) to the mammalian fauna from six different localities in the Madrid Basin. These localities are placed on the Lower or Middle Unit (Calvo, 2000; Montes et al., 2006; Domingo et al., 2009), covering local biozones Dc to $\mathrm{G}$ (15.5 to $13.5 \mathrm{Ma}$ ) according to the micromammal biozonation established by Daams et al. (1999) for the CalatayudDaroca Basin and recognized in the Madrid Basin by PeláezCampomanes et al. (2003). The analysed interval (2 million years) represents a good example to assess this environmental change, because it covers the end of the Miocene Climatic Optimum, together with the end of the Global Cooling Event (Zachos et al., 2001). 


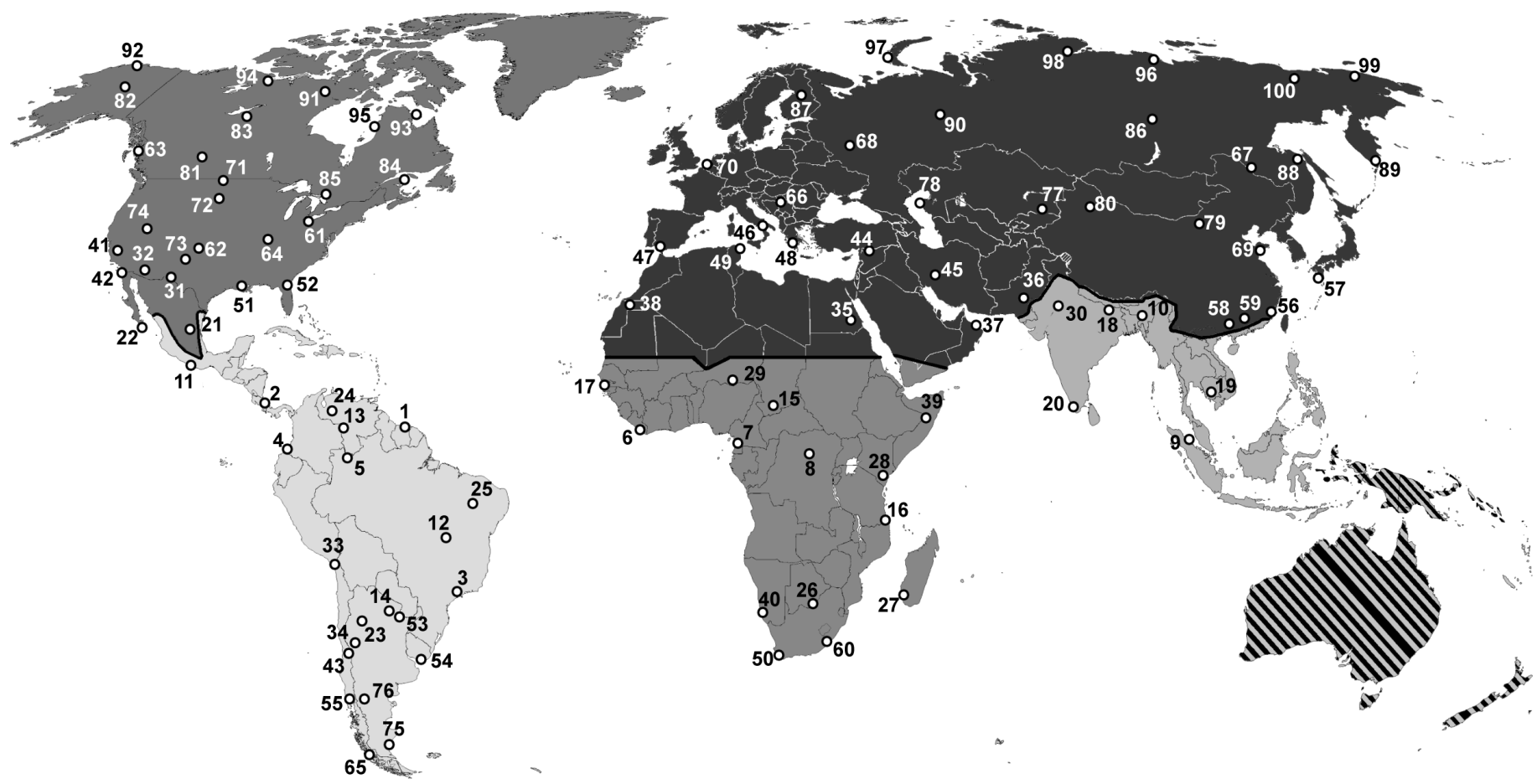

Fig. 1.- Distribution of the 100 modern communities studied in this work. Numbering as in supplementary data I. The different grey shades indicate the different biogeographical realms (light black: Palearctic; dark grey: Nearctic; grey: Afrotropic; silver: Indomalaysia; light grey: Neotropic)

Additionally, in order to generate a comparative framework to assign a specific biome to each fossil assemblage, we described the body size community structures for mammalian prey of 100 modern localities. Finally, since the geological and environmental histories of the continents determine the faunal composition of the different regions (Pickford and Morales, 1994; Moreno Bofarull et al., 2008) and are relevant factors for the mammalian community structure (Croft, 2001; Nieto and Rodríguez, 2003; García Yelo et al., 2009), the influence of biogeography on the relationships was also analysed.

\section{Material and Methods}

\subsection{Extant and fossil faunas}

In order to establish our comparative framework and to test the relationship between body size community structure and climate, we used the climatic data (type of biome) and the mammalian prey faunal data from 100 extant localities (Fig. 1, supplementary data I) uniformly distributed around the world (excluding Australia). Here we followed the biome characterization from Walter (1970), and modified by Hernández Fernández (2001), which represents the 10 climate types present in the Earth today (I: evergreen tropical rainforest; II: tropical deciduous woodland; II/III: savannah; III: tropical desert; IV: sclerophyllous woodland; V: temperate evergreen forest; VI: nemoral broadleaf-deciduous forest; VII: steppe;
VIII: taiga; IX: tundra). Marine and flying mammals, as well as the species introduced by anthropic action, were excluded from our analysis. Nevertheless, those species that were extinct during historic times were incorporated in the database. Taxonomy was standardized to Wilson and Reeder (1993). The body size data for modern species were obtained from Smith et al. (2003). For the few species with no body size information, the mean of the genera was calculated (Rodríguez, 1999; Croft, 2001; Hernández Fernández et al., 2006a). Here we use the concept prey mammals as any terrestrial species, excluding the Australian ones, not belonging to the order Carnivora (Orders Didelphimorphia, Paucituberculata, Microbiotheria, Tubulidentata, Macroscelidea, Hyracoidea, Proboscidea, Xenarthra, Scandentia, Dermoptera, Primates, Rodentia, Lagomorpha, Insectivora, Pholidota, Perissodactyla, and Artiodactyla).

In order to evaluate the climatic evolution of the Madrid Basin before and after the middle Miocene Global Cooling Event, we analysed the body size community structure of prey from six middle Miocene fossil sites from the Madrid Basin (Fig. 2). These localities are: Estación Imperial; Paseo de las Acacias; Arroyo del Olivar-Puente de Vallecas; Somosaguas; Paracuellos 5 and Paracuellos 3. The faunal list of the six localities, together with the body size for fossil species were obtained from Peláez-Campomanes et al. (2003), Hernández Fernández et al. (2006b), Perales et al. (2009) and Hernández-Ballarín et al. (2011), and are detailed in supplementary data II. These fossil sites are among the most com- 
pletely sampled of the Madrid Basin for this period, with a total of 54 species represented and more than 18000 pieces recuperated in successive field works (supplementary data II).

\subsection{Body size Community Structure and Discriminant Analysis}

We used two palaeo-synecological methodologies, cenograms (Legendre, 1986, 1989) and body size spectra (Andrews et al., 1979), to describe the community structure of the mammals present in each locality. Originally, these methodologies were used to visually compare fossil community structure patterns with those from recent mammalian communities and then try to assign a particular habitat to the fossil community.

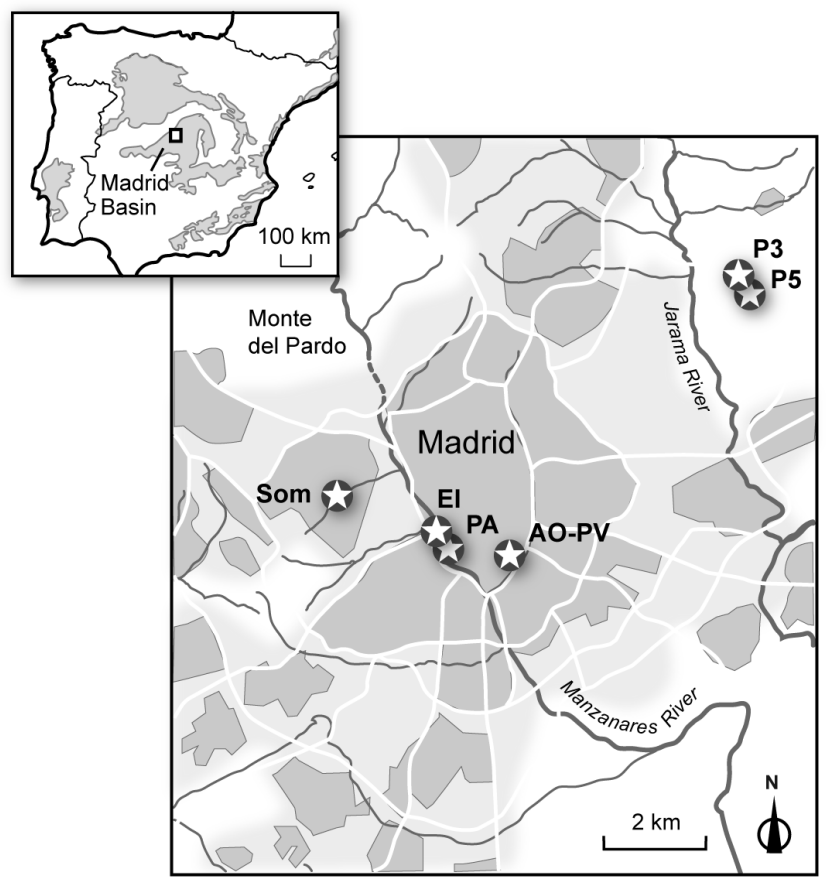

Relative Humidity Curves

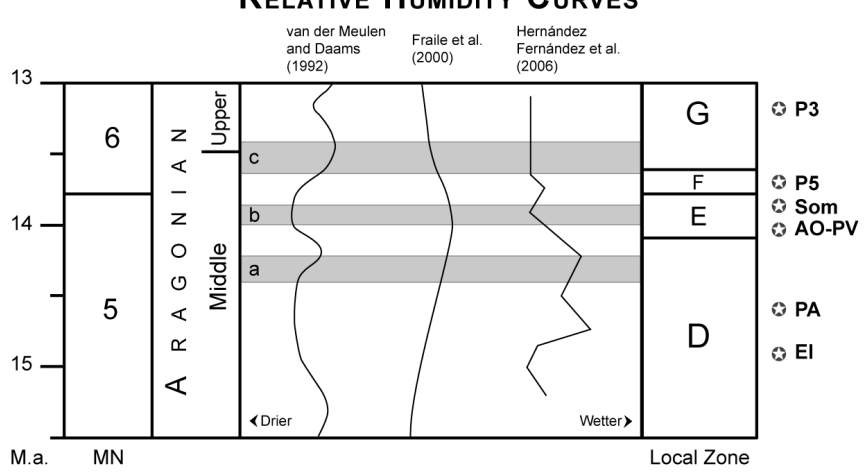

Fig. 2.- Temporal and geographical situation of the six fossil sites used in this analysis. The relative humidity curves of van der Meulen and Daams (1992), Fraile et al. (2000) and Hernández Fernández et al. (2006) are also included to compare with our results. The grey lines indicate the pulses of changes in the aridity conditions. Abbreviations are used as follows: Estación Imperial (EI); Paseo de las Acacias (PA); Arroyo del Olivar - Puente de Vallecas (AO-PV); Somosaguas (Som); Paracuellos 5 (P5) and Paracuellos 3 (P3)

\begin{tabular}{cc}
\hline \multicolumn{2}{c}{ BODY SIZE SPECTRA CATGORIES } \\
\hline Category & Weight range $(\mathrm{g})$ \\
\hline A & $0-100$ \\
B & $100.1-1000$ \\
C & $1000.1-10000$ \\
D & $10000.1-45000$ \\
E & $45000.1-90000$ \\
F & $90000.1-180000$ \\
G & $180000.1-360000$ \\
H & $>360000$ \\
\hline
\end{tabular}

Table 1. Body size categories defined to determine the body size spectra of the mammalian communities used in our study (Andrews et al., 1979; Hernández Fernández et al., 2006).

In body size spectra, every prey mammal from a particular community is assigned to one of the body size categories defined in table 1 (Andrews et al., 1979; Hernández Fernández et al., 2006a). Once each species of the prey community was classified in one of the body size categories and the final sum for each category converted to a percentage, the body size spectrum of the community was obtained. For Legendre's methodology, rank ordered taxa $v s$. body size graphs were plotted. Species were then separated according to body size in four categories, small prey $(<500 \mathrm{~g})$, medium prey $(500$ $\mathrm{g}-8 \mathrm{Kg})$, large prey $(8-1000 \mathrm{Kg})$ and mega-prey $(\geq 1000$ Kg) (Legendre, 1986, 1989; Rodríguez, 1999; Hernández Fernández et al., 2006a). Rodríguez (1999) stated that these body-size thresholds, defined by previous authors (Legendre 1989; Gingerich 1989), respond to trophic and physiological constraints. As mega-prey species are restricted to a few tropical localities, they were excluded from the analysis in order to make the results more comparable among the different communities. Finally, twelve cenogram variables (Fig. 3, Table 2) were defined to describe the mammalian body size structure of the communities. Both Rodríguez (1999) and Hernández Fernández et al. (2006a) selected these variables because of their ecological significance. Although the limits between categories are fixed, the number of species present in those categories can vary as a consequence of the predator pressure (Valverde 1967). Thus, while the different mean weight or body mass $(\mathrm{Wx}$ ) reveals the more suitable size to avoid predator pressure in each category, the magnitude of the different gaps $(\mathrm{G}, \mathrm{mG}$ and $\mathrm{MG})$ and its position on the cenogram (WG, WmG and WMG) depict exactly the opposite. Finally the slopes in the cenogram were defined in order to state the species-richness in each category (Gingerich 1989).

Taphonomic biases might have affected mammalian diversity and structure of the fossil communities, making a rarefaction analysis necessary. Nevertheless, as previous studies have revealed, a high number of species have to be lost to significantly affect the structure of a community (Gómez Cano et al. 2006). Due to the high sample size of the fossil sites used in this study, the possibility of taphonomic biases may be discarded. 


\begin{tabular}{|c|c|}
\hline \multicolumn{2}{|r|}{ CENOGRAM VARIABLES } \\
\hline Variables & Description \\
\hline W1 & $\begin{array}{l}\text { Mean weight or body mass of all small prey } \\
(<500 \mathrm{~g}) \text { (in logarithmic units) }\end{array}$ \\
\hline W2 & $\begin{array}{l}\text { Mean weight or body mass of all medium prey } \\
\quad(500 \mathrm{~g}-8 \mathrm{Kg}) \text { (in logarithmic units) }\end{array}$ \\
\hline W5 & $\begin{array}{l}\text { Mean weight or body mass of all medium-large prey } \\
(500 \mathrm{~g}-1000 \mathrm{Kg}) \text { (in logarithmic units) }\end{array}$ \\
\hline $\mathrm{P} 1$ & $\begin{array}{l}\text { Slope of the line segment determined by small prey } \\
\qquad(<500 \mathrm{~g})\end{array}$ \\
\hline P5 & $\begin{array}{l}\text { Slope of the line segment determined by medium-large } \\
\text { prey }(500 \mathrm{~g}-1000 \mathrm{Kg})\end{array}$ \\
\hline P5-P1 & $\begin{array}{l}\text { Difference in slope between the line segments deter- } \\
\text { mined by medium-large and small prey }\end{array}$ \\
\hline G & $\begin{array}{c}\text { Magnitude of the gap between small and medium-large } \\
\text { prey (in logarithmic units) }\end{array}$ \\
\hline $\mathrm{mG}$ & $\begin{array}{l}\text { Magnitude of the major gap between two consecutive } \\
\text { species of medium-large prey (in logarithmic units) }\end{array}$ \\
\hline MG & $\begin{array}{l}\text { Magnitude of the major gap between two consecutive } \\
\text { species of all prey (in logarithmic units) }\end{array}$ \\
\hline WG & $\begin{array}{l}\text { Mean weight or body mass of the two species that } \\
\text { define } G \text { (in logarithmic units) }\end{array}$ \\
\hline WmG & $\begin{array}{l}\text { Mean weight or body mass of the two species that } \\
\text { define } \mathrm{mG} \text { (in logarithmic units) }\end{array}$ \\
\hline WMG & $\begin{array}{c}\text { Mean weight or body mass of the two species that } \\
\text { define MG (in logarithmic units) }\end{array}$ \\
\hline
\end{tabular}

Table 2. Cenogram variables defined to describe the mammal community structure based on the cenogram methodology (Valverde, 1964, 1967; Hernández Fernández et al., 2006)

Once the community structure and biome of modern faunas were defined in each locality, we tried to establish a statistical relation between the type of biome and a specific community structure pattern. Following Hernández Fernández et al. (2006a) we performed a multivariate discriminant analysis of the dataset containing modern faunal information in or- der to assess the statistical capability of both methodologies to distinguish between biomes. In a second analysis the different biogeographic histories of the continents were taken into account; thus, the test was repeated independently with localities grouped by their respective biogeographic realms. Conceptually, this forced us to remove from the study those localities that belong to biomes represented by only one community in a biogeographic realm. Consequently, only tropical biomes are represented in the tropical realms of the Old World, and the Indomalaysian region only included evergreen tropical rainforest and tropical deciduous woodland biomes. Additionally, due to a likely Palaeotropical origin of the Miocene mammals from the Iberian Peninsula (Pickford and Morales, 1994) and the climatic similarities between the modern tropical realms and the Iberian Peninsula during the Miocene (Hernández Fernández et al., 2006a), we carried out a new analysis where the localities within the Afrotropical and Indomalaysian realms were grouped together. Thus, the biomic inference for the fossil sites was based on the Afrotropical, Indomalaysian and Palaeotropical discriminant models.

\section{Results}

Discriminant analyses applied to body size spectra and cenogram variables from the modern fauna have shown a low biome discriminant capability of both methodologies at the global scale $(47 \%$ and $55.7 \%$ of correctly classified localities respectively). However, our results were significantly improved when the analyses were repeated separating communities by biogeographic realms (Table 3), indicating a noteworthy influence of the evolutionary history on prey community structure based on their body size distributions.

In order to examine which body size variables made the strongest contribution to discriminate biomes in every analysis, the principal components that discriminate biomes in our study have been studied (supplementary data III). While for
Fig. 3.- Cenogram associated with the mammal community of Patna (India). Black circles, small prey; white circles, middle-size prey; black blocks, large prey. Variables of the cenogram as in table 2 .

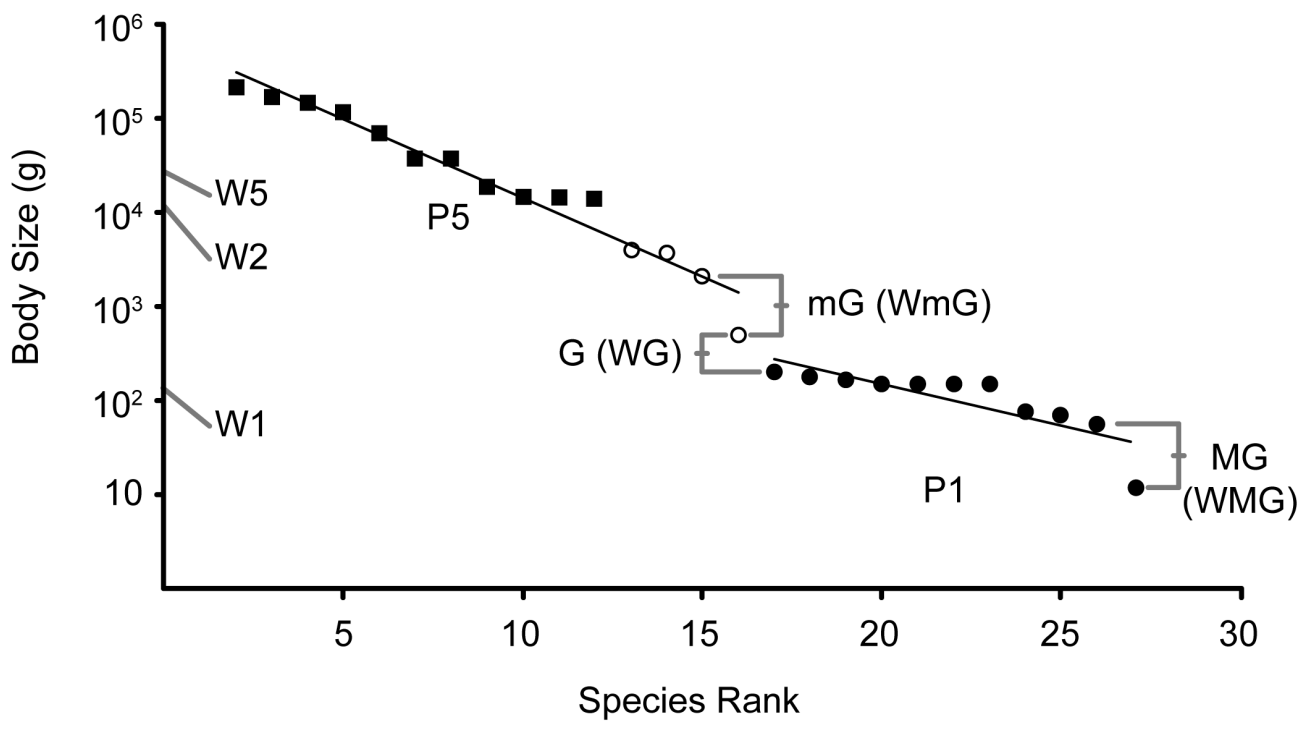


A

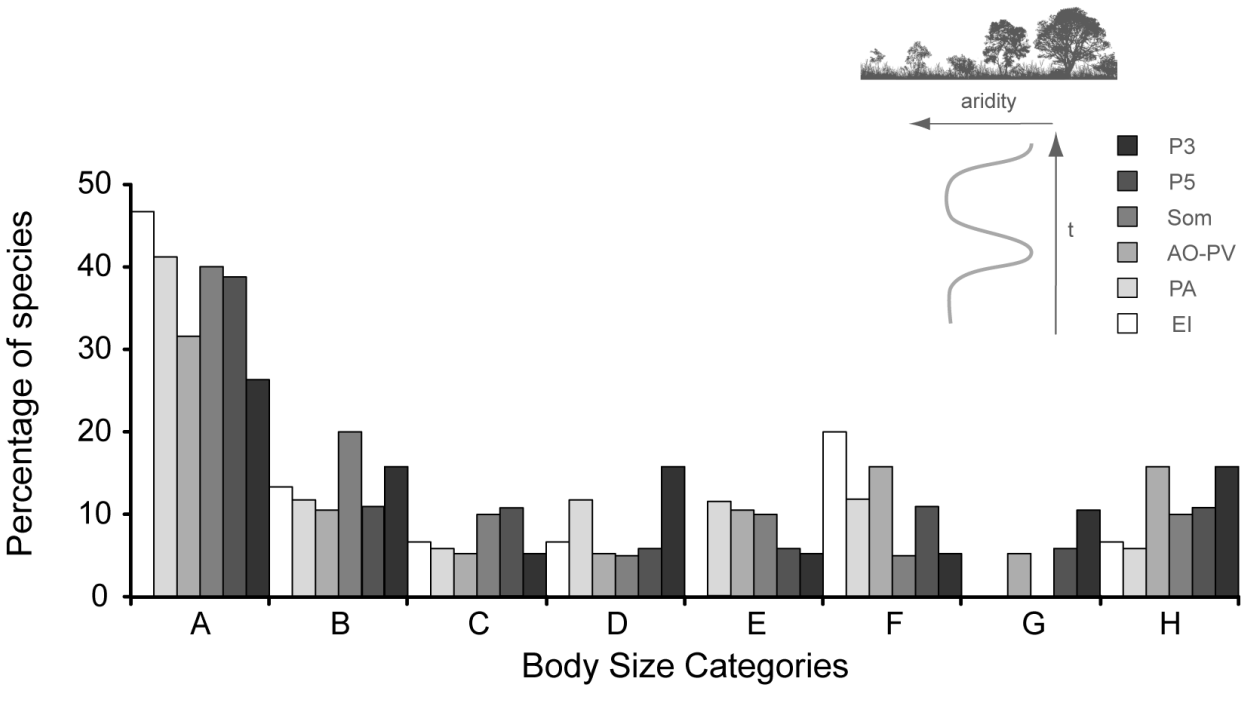

B

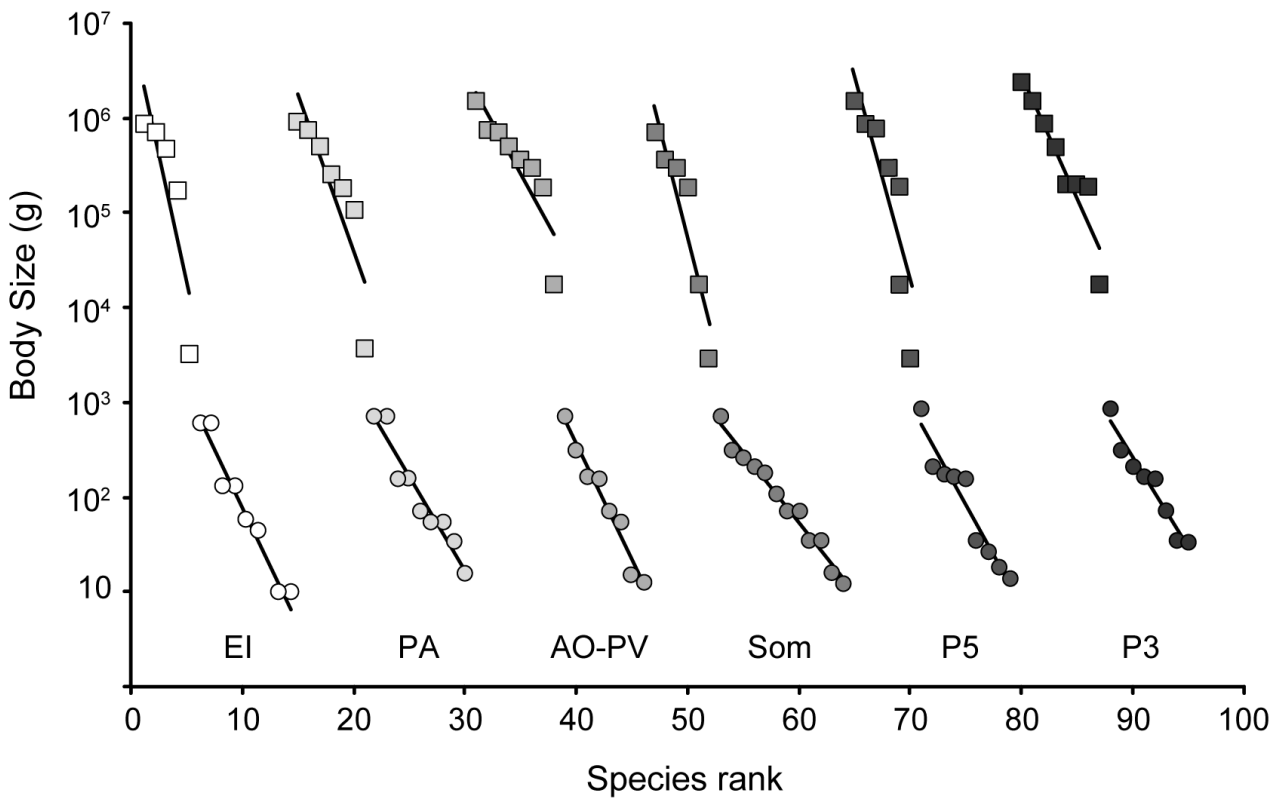

Fig. 4.- Resume figure with a compendium of the six body size spectra (A) and the cenograms (B) obtained for the Aragonian palaeocommunities. A schematic aridity curve is provided for the analysis interval. Abbreviations are used as follows: Estación Imperial (EI); Paseo de las Acacias (PA); Arroyo del Olivar - Puente de Vallecas (AO-PV); Somosaguas (Som); Paracuellos 5 (P5) and Paracuellos 3 (P3) cenogram global analysis are the slope variables (P5, P5$\mathrm{P} 1, \mathrm{G}, \mathrm{W} 1$ and $\mathrm{WG})$ the principal ones that contribute to discriminate biomes, for the biogeographic realms analyses different variables contribute to separate biomes in every region. While for the Indomalaysian realm the mean weight variables (W1, W2 and W5) are the ones that discriminate biomes, for the Afrotropic and the Palaeotropic most of the cenogram variables seem to help to discriminate biomes. In the body size spectra case, body size categories A and E are the main contributors to the global discrimination of biomes. Nevertheless, when the discriminant analyses are repeated by biogeographic realms, different categories separate biomes in each biogeographic region, with all body size categories being represented (supplementary data III).

Once the discriminant models for the Afrotropical, Indomalaysian and Palaeotropical realms were performed, the biomic inference for the six fossil sites were obtained (Table 4). Given a particular biogeographic region (e.g., Afrotropic), the inferred biome for the same fossil locality (e.g., Estación Imperial) is different using each methodology (tropical deciduous woodland and tropical desert). All predicted biomes, excluding the evergreen tropical rainforest detected by the Indomalaysian realm, are arid and warm.

These results are complex and make the use of both methodologies to infer biomes complicated. Nevertheless, a common pattern can be asserted. Changes in the aridity and forest density through time can be detected by cenograms (for all realms analysed) and the body size spectra (for the Palaeotropical realm). It is worth mentioning that most of these changes are detected synchronously by both methods in most of the cases (Table 4). The studied period started with an arid/ semiarid and scarcely forested environment (II or III biomes were obtained for Estación Imperial and Paseo de las Acacias) that was followed by a climatic change to relative more wooded-humid conditions between biozones D and E (I, II, II/III biomes for Arroyo del Olivar-Puente de Vallecas). After 
Table 3. Results of the discriminant analyses for the extant communities at global level and by biogeographic realms (biome clasification as in the text). ${ }^{*}$ The $\mathrm{N}$ (numbers of localities) noted with an asterisk reflects those cases where the localities included in the analysis are not the same for both methodologies (given number refers to the BBS method). The number of included localities for cenogram method is: 97 (for global analysis), 15 (for Neotropic) and 32 (for Palaearctic) **The double asterisk indicates that the number of biomes included in the Neotropics is also different in both methods, being the given biomes those for the BBS method, while for cenogram method are I, II, II/III and V.

\begin{tabular}{|c|c|c|c|c|}
\hline & & \multirow{2}{*}{$\begin{array}{c}\mathbf{N} \\
\text { (INCLUDED } \\
\text { BIOMES) }\end{array}$} & \multicolumn{2}{|c|}{$\begin{array}{c}\text { CORRECTLY CLASSIFIED } \\
\text { COMMUNITIES }\end{array}$} \\
\hline & & & BSS & CENOGRAMS \\
\hline \multicolumn{2}{|r|}{ GLOBAL } & $\begin{array}{c}100^{*} \\
(\mathrm{I}-\mathrm{IX})\end{array}$ & $47.0 \%$ & $55.7 \%$ \\
\hline \multirow{5}{*}{ 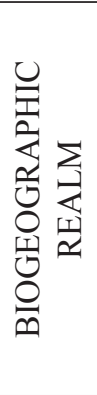 } & NEARCTIC & $\begin{array}{c}26 \\
\text { (II/III-IX) }\end{array}$ & $65.4 \%$ & $96.2 \%$ \\
\hline & NEOTROPIC & $\begin{array}{c}19^{*} \\
(\mathrm{I}, \mathrm{II}, \mathrm{II} / \mathrm{II}, \mathrm{V}, \mathrm{VII})^{* *}\end{array}$ & $73.7 \%$ & $100.0 \%$ \\
\hline & PALEARCTIC & $\begin{array}{c}33^{*} \\
\text { (III-IX) }\end{array}$ & $72.7 \%$ & $84.4 \%$ \\
\hline & AFROTROPIC & $\begin{array}{c}12 \\
(\mathrm{I}-\mathrm{III})\end{array}$ & $91.7 \%$ & $100.0 \%$ \\
\hline & INDOMALAYSIA & $\begin{array}{c}5 \\
(\mathrm{I}-\mathrm{II}) \\
\end{array}$ & $100.0 \%$ & $60.0 \%$ \\
\hline \multicolumn{2}{|r|}{ PALEOTROPIC } & $\begin{array}{c}18 \\
\text { (I-III) }\end{array}$ & $77.80 \%$ & $100.0 \%$ \\
\hline
\end{tabular}

Table 4. Inferred biomes for the six fossil sites included in the analysis. The grey colours mean different trends in the hydric gradient; relatively more humid climates are marked with dark grey and relatively more arid biomes with light grey. Abbreviations are used as follows: Estación Imperial (EI); Paseo de las Acacias (PA); Arroyo del Olivar - Puente de Vallecas (AO-PV); Somosaguas (Som); Paracuellos 5 (P5) and Paracuellos 3 (P3)

\begin{tabular}{|c|c|c|c|c|c|c|c|}
\hline & & EI & PA & AO-PV & Som & P5 & P3 \\
\hline \multirow{3}{*}{ 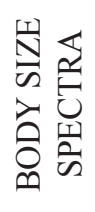 } & AFROTROPIC & II & II & II & II & II & II \\
\hline & INDOMALAYSIA & I & I & I & I & I & II \\
\hline & PALAEOTROPIC & III & III & II & II/III & II/III & II \\
\hline \multirow{3}{*}{ 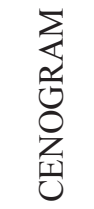 } & AFROTROPIC & III & III & II/III & III & II/III & II/III \\
\hline & INDOMALAYSIA & II & II & I & II & II & I \\
\hline & PALAEOTROPIC & III & II & II & III & III & II \\
\hline
\end{tabular}

a short lapse of time (still inside biozone E), arid and less forested conditions returned (II, II/III or III for Somosaguas and Paracuellos 5). Finally, a new environmental change to more forested and humid conditions (I, II, II/III biomes for Paracuellos 3) took place between biozones F and G.

Nevertheless, it is also worth mentioninig that the results given by the body size spectra for the Indomalaysian realm show an homogeneous climate during most of the sequence excepting at the end, where a climatic change between humid to arid conditions (from biome I to II) was produced, showing an inversion of the pattern (table 4). Finally, regardless of the high inference potential of the body size spectra for the modern localities of the Afrotropical region, this method does not detect any environmental change for the whole sequence of the fossil sites under study.

\section{Discussion}

Our results show changes in climate during the middle Miocene in the Madrid Basin, with a fluctuation between arid and relatively more humid conditions. All the climates inferred for the different fossil sites in this research are tropical, and most of them show aridity at some level. Previous studies also found a tropical warm and arid climate for the Iberian Peninsula during this time span. Amezua et al. (2000) used several palaeo-synecological methodologies (ecological diversity spectra, cenograms, diversity indexes, quantitative species composition and presence/absence of environmental indicative species) to analyse the environmental evolution of the Madrid Basin over the middle Aragonian. They found very homogeneous conditions for the Madrid Basin through the middle Miocene, with warm and arid environments with slight variations in the humidity. Hernández Fernández et al. (2006a) also used ecological diversity and cenograms to recognise aridity peaks, by means of biome characterization, through the middle Aragonian of Spain. All fossil sites were classified as tropical deciduous forest (II), savannah (II/III) or tropical desert (III) (excluding three of them classified as temperate evergreen forest by the trophic diversity model), which are warm and relatively arid biomes. Costeur and Legendre (2008) analysed the mammalian body-weight structure of 17 fossil communities from middle Miocene (17-14 M.a.) 
from Spain and Germany, finding a southwest-northeast latitudinal environmental gradient, from a warm, arid and open environment in Spain to a warm, closed and humid environment in Germany.

In most of the discriminant models a common pattern can be detected. At the beginning (coincidently with the Miocene Climatic Optimum) and the middle of the sequence (after the Global Cooling Event), two lapses of time corresponding to local zones Dc and E-F (including Estación Imperial, Paseo de las Acacias, Somosaguas and Paracuellos 5 fossil sites), the prey community structures of the fauna present in the Madrid Basin reflect more open and arid conditions (desert, tropical deciduous woodland or savannah) than the rest of the sequence in the different discriminant models. The rest of the sequence (Arroyo del Olivar-Puente de Vallecas and Paracuellos 3 fossil site communities) represents more humid and closed environments (evergreen tropical rainforest, tropical deciduous woodland or savannah). Although the same biome classification was estimated for some sites of both environment types, arid and relatively humid localities, such overlap is rarely obtained within the same discriminant model. Our results suggest that three environmental fluctuations took place during this period. The first and third climatic changes (between Paseo de las Acacias and Arroyo del Olivar-Puente de Vallecas, and between Paracuellos 5 and Paracuellos 3) were toward relatively more humid and forested conditions. The second one (between Arroyo del Olivar-Puente de Vallecas and Somosaguas) coincided with the middle Miocene Global Cooling Event and reflects more arid conditions. The relative humidity curves given by Meulen and Daams (1992) and Hernández Fernández et al. (2006b), based in changes in the structure of rodent faunas, depict aridity peaks that match in time with the climatic change towards more open and arid environments detected in the present study (Fig. 2). Fraile et al. (2000) also detected these changes in mammal faunas from the Madrid Basin although they noticed small differences on the time limits between arid and humid environments (Fig. 2). Finally, isotopic analysis of tooth enamel of middle Miocene ungulates from the Madrid Basin also shows similar results, with fluctuations between arid and relatively humid periods (Domingo et al., 2012).

When the six body size spectra and cenograms from the fossil communities are represented together (Fig. 4), further interpretations can be made. James (1970) found that birds in cold and dry environments were smaller than their relatives in warm and humid ones, so the relative large $v s$. small birds ratio should grow from dry to humid environments. If we extrapolate this concept to mammalian communities, the proportion of small species should decrease from dry environments to humid ones, whereas large species would become more frequent as the aridity of the environment decreases. Analysing the body size spectrum of the different extinct communities (Fig. 4a), different ratios of large vs. small mammals can be noticed. In dryer localities (Estación
Imperial, Paseo de las Acacias, Somosaguas and Paracuellos 5), small mammals (characterized by body size category A) are over represented (above the $40 \% ; \bar{X}=42.25 \%$ ), and the large $v s$. small mammals (categories $\mathrm{G}$ and $\mathrm{H}$; cat $[\mathrm{G}+\mathrm{H}] /$ catA ratio) ratio is small ( $\bar{X}=0.24)$. On the other hand, in relatively more humid localities (Arroyo del Olivar-Puente de Vallecas and Paracuellos 3), small mammals are drastically reduced (in both cases under the $32 \% ; \bar{X}=28.95 \%$ ) and the large $v s$. small mammals ratio is higher $(\bar{X}=0.83)$. These differences in the body size diversity structure between arid and relatively humid fossil communities are statistically significant (small mammals: $\mathrm{T}=-4.816, \rho=0.009$; large $v s$. small mammals ratio: $T=4.122, \rho=0.015$ ). Nevertheless, these differences have not been found in the modern fauna (small mammals: $\bar{X}_{\text {humid }}=48.94 \%, \bar{X}_{\text {arid }}=43.92 \%, \mathrm{~T}=1.783, \rho=0.078$; large $v s$. small mammals ratio: $\bar{X}_{\text {humid }}=0.08, \bar{X}_{\text {arid }}=0.12, \mathrm{~T}=-1.538$, $\rho=0.128$ ), maybe as a consequence of the interaction of some other climatic factors, such as temperature, over the body size of mammals (Bergmann rule).

This pattern is also reflected for macromammals in the cenogram structure of the different fossil communities (Fig. 4b), where the slope of the line that defines medium-large prey (P5) is statistically different between arid and relatively humid fossil sites ( $\mathrm{T}=-3.078, \rho=0.037)$, being more pronounced in arid localities $(\bar{X}=-0.88)$ than in the relatively humid ones $(\bar{X}=-0.47)$. Furthermore, these differences are also detected in the modern fauna $\left(\bar{X}_{\text {humid }}=-1.02 ; \bar{X}_{\text {arid }}=-0.695 ; \mathrm{T}=2.099\right.$, $\rho=0.039$ ). Interestingly, the cenograms for these fossil sites contradict one of the most accepted rules for aridity and cenogram structure. As Legendre defined $(1986,1989)$, the magnitude of the gap between small and medium-large prey is related to the aridity of the environment; the more arid the climate is, the larger the gap. But in our results statistically larger gaps are present in the humid localities ( $\mathrm{T}=$ 9.729, $\left.\rho=0.001 ; \bar{X}_{\text {humid }}=2.70 ; \bar{X}_{\text {arid }}=1.28\right)$. Again, these differences are also detected in the modern fauna $\left(\bar{X}_{\text {humid }}=1.32\right.$; $\bar{X}_{\text {arid }}=0.93 ; \mathrm{T}=-2.092, \rho=0.040$ ). In the fossil sites, this is a consequence of the absence in Arroyo del Olivar-Puente de Vallecas and Paracuellos 3 of the species Cainotherium miocaenicum or a member of the genus Amphechinus, the latter showing a clear preference for arid environments (Furió et al., 2011). This fact could be a consequence of taphonomic bias against the preservation of small mammals in closed environments (Cantalapiedra et al., 2012), but since this difference is also detected in the modern fauna, we suggest that this pattern could be a consequence of the higher hydric constrictions of large prey mammals. Water is an environmental conditioning factor that forces large animals to inhabit preferentially more closed and humid environments (Robertshaw and Taylor, 1969; McNab, 2002) and consequently, smaller species would find benefits in get adapted to arid environments in order to avoid competition. 
Also the species composition of the fossil sites corroborates our results. An important proportion of the species of our fossil communities are typically arid-adapted taxa, as inhabitants of arid localities. However, the presence of a few taxa allows us to assess further details of the environment (more arid and open, or more humid and close). For example, arid conditions are reflected in the presence of Hispanotherium matritense or Anchitherium cursor, two perissodactyls with hypsodont dentition and relatively gracile limbs that are adapted to open and arid conditions (Cerdeño and Nieto, 1995; Soria et al., 2000; Salesa et al., 2001; Hernández Fernández et al., 2003), or several members of the order Rodentia, such as Armantomys, Microdyromys, Democricetodon or Cricetodon (Weerd and Daams, 1978; Meulen and de Bruijn, 1982; Daams and Meulen, 1984; Mein, 1983; Sesé et al., 1985). This supports the idea of a more arid an open environment for Estación Imperial, Paseo de las Acacias, Somosaguas and Paracuellos 5 fossil sites. On the contrary, all these taxa are absent in Arroyo del Olivar-Puente de Vallecas and Paracuellos 3, whereas other forest-adapted dwellers are found, pointing to a more closed and less arid environment. Some examples of such forest-adapted faunas are Chalicotherium grande, a perissodactyl with longer forelimbs and a brachiodont dentition (Sánchez, 2000); cervids such as Euprox furcatus, a browser with preferences for arboreal vegetation (Soria et al., 2000), or the rhinoceros Lartetotherium sansaniense with shorter and slightly more robust limbs than Hispanotherium (Sánchez-Chillón and Cerdeño, 2000).

Additionally, the presence of thermophile species, such as Lagopsis penai, Lagopsis verus, Microdyromys koenigswaldi, Microdyromys monspeliensis (López Martínez, 1977; Meulen and de Bruijn, 1982; Daams and Meulen, 1984; Mein, 1983; Sesé et al., 1985; Luis and Hernando, 2000) in all the fossil localities confirms the warm conditions of the Madrid Basin during the sequence.

\section{Conclusions}

While at the global scale body size spectra and cenogram methodologies seem to have low capability to discriminate biomes from the data in modern localities, when the biogeographic histories of modern faunas are considered, body size community structure of prey mammals emerges as a good proxy for inferring biomes. Nevertheless, when the method is applied to the fossil record, the biome inferences may appear inaccurate, although fluctuations in climate and environments are precisely recovered.

Compared with the extant mammals from the Palaeotropics, the body size community structures of the Aragonian mammals present in the Madrid Basin allowed us to infer a predominance of semiarid environments between 15.5 and 13.5 Ma. Additionally, the methodologies used here allowed us to clearly distinguish several pulses of distinctive aridity throughout the whole sequence. A phase of arid climate and open environments was detected at the beginning of the sequence (Estación Imperial and Paseo de las Acacias fossil sites), which was followed by an environmental change towards a more humid and forested phase (Arroyo del OlivarPuente de Vallecas). Arid conditions and grass-dominated habitats returned to central Iberia associated to the Global Cooling Event of the middle Miocene (coinciding with Somosaguas fossil site age). At the end of the sequence (Paracuellos 3 fossil site) the landscape returned to a more covered and humid scenario.

When the body size community structure of the fossil faunas was deeply analysed, a positive influence of the aridity over the relative percentages of small prey was recovered. Nevertheless, this influence is masked by other climatic factors (e.g. temperature) in the actual faunas. Nonetheless, cenogram methodology also detects this influence, not only in fossil sites, but also in the extant mammalian communities. The slope of the line that defines medium to large prey (P5) is more marked in arid environments than in relatively more humid ones. The magnitude of the gap between small and medium-large (G) prey also shows this influence, having bigger gaps in humid localities. This contradicts Legendre's more accepted rules over cenograms, which stated that the more arid the environment is, the larger the gap between small and medium-large prey. Nevertheless, our methodology uses a macro-scale approach to analyse climatic evolution, and some differences are expected if a smaller geographical scale is taken into account.

\section{Acknowledgement}

Authors would like to thank Dr. Marc Furió, Dr. Israel García Paredes, Dr. Lars van den Hoek Ostende, Dr. Pablo Peláez-Campomanes and Dr. Israel Sánchez for their help and assistance. The editors, as well as the referees Catherine Badgley (University of Michigan), Serge Legendre (Université Claude Bernard Lyon 1) and an anonymous referee are acknowledged for their valuable comments, which helped to improve the last version of this manuscript. Aisling Farrell (Page Museum - La Brea Tar Pits, Natural History Museum of Los Angeles County) is acknowledged for her correction of the English usage. This is a contribution of the PMMV Team (Palaeoecology, Macroecology and Macroevolution of Vertebrates (http://pmmv.com.es) as part of the research group UCM-910607 on Evolution of Cenozoic Mammals and Continental Palaeoenvironments. This work was supported by projects of the Spanish Ministries of Education, Science and Innovation (CGL2008-04200/BTE, CGL-200805813-C02-01/BTE， CGL2010-19116/BOS， CGL201128877, CGL2011-25754), as well as FPU predoctoral contracts granted to BAGY, AO and OS, a FPI predoctoral contract granted to VH-B and a UCM predoctoral contract granted to PL-G. 


\section{References}

Alba, D.M., Agustí, J., Moyà-Solà, S. (2001): Completeness of the mammalian fossil record in the Iberian Neogene. Paleobiology 27, 79-83. doi: 10.1666/0094-8373(2001)027<0079:COTMFR>2.0.CO;2.

Alberdi, M.T. (1985): Geología y Paleontología del Terciario continental de la provincia de Madrid. Consejo Superior de Investigaciones Científicas. MNCN, Madrid: 1-105 p.

Allen A.J. (1877): Allen's rule. The influence of Physical conditions in the genesis of species. Radical Review 1, 108-140.

Amezua, L., Salesa, M.J., Pérez, B., Peláez-Campomanes, P., Fraile, S., Morales, J., Nieto, M. (2000): Paleoecología. In: J. Morales (coord.), Patrimonio paleontológico de la Comunidad de Madrid. Consejería de Educación de la Comunidad de Madrid, Madrid: 155-172.

Andrews, P., Lord, J.M., Evans, J.P. (1979): Patterns of ecological diversity in fossil and modern mammalian faunas. Biological Journal of the Linnean Society 11, 177-205. doi: 10.1111/j.1095-8312.1979. tb00034.

Ashton, K.G. (2001): Sensitivity of intraspecific latitudinal clines of body size for tetrapods to sampling, latitude and body size. Integrative and Comparative Biology 44, 403-412. doi: 10.1093/icb/44.6.403.

Ashton, M., Tracy, C., de Queiroz, A. (2000): Is Bergmann's Rule Valid for Mammals? The American Naturalist 156, 390-415. doi: 10.1086/303400.

Barnosky, A.D. (2001): Distinguishing the effects of the Red Queen and Court Jester on Miocene mammal evolution in the northern Rocky Mountains. Journal of Vertebrate Paleontology 21, 172-185. doi:10.1671/0272-4634(2001)021[0172:DTEOTR]2.0.CO;2.

Bergmann, C. (1847): Uber die verhaltnisse der warmeokonomie der thiere zu ihrer grosse. Göttinger Studien 3, 595-708.

Böhme, M., (2003): The Miocene Climatic Optimum: evidence from ectothermic vertebrates of Central Europe. Palaeogeography, Palaeoclimatology, Palaeoecology 195, 389-401. doi: 10.1016/S00310182(03)00367-5.

Böhme, M., Winklhofer, M., Ilg, I. (2010): Miocene precipitation in Europe: Temporal trends and spatial gradients. Palaeogeography, Palaeoclimatology, Palaeoecology 304, 212-218. doi: 10.1016/j.palaeo.2010.09.028.

Boyce, M.S. (1978): Climatic variability and body size variation in muskrats (Ondatra-Zibethicus) of north-America. Oecologia 36 (1), 1-19. doi: 10.1007/BF003445671.

Calvo, J.P. (1989): Hoja geológica num. 559 (Madrid). Mapa Geológico de España E. 1:50.000. Segunda serie, I.G.M.E., Madrid.

Calvo, J.P. (2000): Geología. In: J. Morales (coord.), Patrimonio paleontológico de la Comunidad de Madrid. Consejería de Educación de la Comunidad de Madrid, Madrid: 58-65.

Calvo, J.P., Daams, R., Morales, J., López-Martínez, N., Agustí, J., Anadón, P., Armenteros, I., Cabrera, L., Civis, J., Corrochano, A., Díaz Molina, M., Elizaga, E., Hoyos, M., Martín-Suárez, E., Martínez, J., Moissenet, E., Muñoz, A., Pérez García, A., Pérez-González, A., Portero, J.M., Robles, F., Santisteban, C., Torres, T., Meulen, A.J. van der, Vera, J.A., Mein, P. (1993): Up-to-date Spanish continental Neogene synthesis and paleoclimatic interpretation. Revista de la Sociedad Geológica de España 6, 29-40.

Cantalapiedra, J.L., Hernández Fernández, M., Alcalde, G., Azanza, B., DeMiguel, D., Morales, J. (2012): Ecological correlates of ghost lineages in ruminants. Paleobiology 38, 101-111. doi: 10.1666/09069.1.

Carrasco, A., Sacristán, S., Benítez-López, G., Romero-Nieto, D., Fesharaki, O., López-Martínez, N. (2008): Aplicaciones paleoclimáticas y paleoambientales de los estudios mineralógicos al yacimiento de vertebrados miocenos de Somosaguas. Paleontologica Nova 8, 135149.

Cerdeño, E., Nieto, M. (1995): Changes in Western European Rhinocerotidae related to climatic variations. Palaeogeography, Pal- aeoclimatology, Palaeoecology 114, 325-338. doi: 10.1016/00310182(94)00085-M.

Clift, P.D. (2010): Enhanced global continental erosion and exhumation driven by Oligo-Miocene climate change. Geophysical Research Letters 37, L09402. doi:10.1029/2010GL043067.

Costeur, L., Legendre, S. (2008): Mammalian Communities Document a Latitudinal Environmental Gradient during the Miocene Climatic Optimum in Western Europe. Palaios 23, 280-288. doi: 10.2110/ palo.2006.p06-092r.

Costeur, L, Legendre, S, Aguilar, J-P, Lecuyer, C. (2007): Marine and continental synchronous climatic records: Towards a revision of the European Mid-Miocene mammalian biochronological framework. Geobios-Lyon 40, 775-84. doi: 10.1016/j.geobios.2007.07.001.

Croft, D.A. (2001): Cenozoic environmental change in South America as indicated by mammalian body size distributions (cenograms). Diversity and Distributions 7, 271-87. doi: 10.1046/j.13669516.2001.00117.x.

Daams, R., Freudenthal, M., Weerd, A. van de (1977): Aragonian, a new stage for continental deposits of Miocene age. Newsletters on Stratigraphy $6,42-55$.

Daams, R., Meulen, A.J. van der (1984): Paleoenvironmental and Paleoclimatic interpretation of Micromammal faunal successions in the Upper Oligocene and Miocene of North Central Spain. In J. Meulenkamp (ed.), Paleoenvironnements continentaux en Méditerrannée au Néogène et évolution paléoclimatique 14, Paleobiologie Continentale: 241-257.

Daams, R., Meulen, A.J. van der, Álvarez-Sierra, M.A., Peláez-Campomanes, P., Calvo, J.P., Alonso Zarza, M.A., Krijgsman, W. (1999): Stratigraphy and sedimentology of the Aragonian (Early to Middle Miocene) in its type area (North-Central Spain). Newsletters on Stratigraphy 37, 103-39.

DeMiguel, D., Azanza, B., Morales, J. (2011): Paleoenvironments and paleoclimate of the Middle Miocene of central Spain: A reconstruction from dental wear of ruminants. Palaeogeography, Palaeoclimatology, Palaeoecology 302, 452-63. doi: 10.1016/j.palaeo.2011.02.005.

Domingo, L., Cuevas-González, J., Grimes, S., Hernández Fernández, M., Lopez-Martinez, N. (2009): Multiproxy reconstruction of the palaeoclimate and palaeoenvironment of the Middle Miocene Somosaguas site (Madrid, Spain) using herbivore dental enamel. Palaeogeography Palaeoclimatology Palaeoecology 272, 53-68. doi: 10.1016/j. palaeo.2008.11.006.

Domingo, L., Koch, P. L., Grimes, S., Morales, J., Lopez-Martinez, N. (2012): Isotopic paleoecology of mammals and the Middle Miocene Cooling event in the Madrid Basin (Spain). Palaeogeography Palaeoclimatology Palaeoecology 339-341, 98-113. doi: 10.1016/j.palaeo.2012.04.026.

Fleming, T.H. (1973): Numbers of mammals species in north and central American forest communities. Ecology 54, 555-563.

Fraile, S., Amezua, L., Morales, J., Nieto, M., Peláez-Campomanes, P., Salesa, M. J., Sánchez, I.M. (2000): Marco general del Terciario. In: J. Morales (coord.), Patrimonio paleontológico de la Comunidad de Madrid. Consejería de Educación de la Comunidad de Madrid, Madrid: 85-101.

Fuentes, E., Jaksić, F.M. (1979): Latitudinal Size Variation of Chilean Foxes: Tests of Alternative Hypotheses. Ecology 60, 43-47.

Furió, M., Casanovas-Vilar, I., Hoek Ostende, L.W. van den (2011): Predictable structure of Miocene insectivore (Lipotyphla) faunas in Western Europe along a latitudinal gradient. Palaeogeography, Palaeoclimatology, Palaeoecology 304, 219-29. doi: 10.1016/j.palaeo.2010.01.039.

García Yelo, B.A., Hernández Fernández, M., Morales, J. (2009): The community structure of carnivore mammals, a key to infer the climate. Journal of Vertebrate Paleontology 29 (3-Supplement), 102A.

Gingerich, P.D. (1989): New earliest Wasatchian mammalian fauna from 
the Eocene of northwestern Wyoming: composition and diversity in a rarely sampled high-floodplan assemblage. University of Michigan. Papers on Paleontology 28, 1-97.

Gómez Cano, A.R., García Yelo, B.A., Hernández Fernández, M. (2006): Cenogramas, análisis bioclimático y muestreo en faunas de mamíferos: implicaciones para la aplicación de métodos de análisis paleoecológico. Estudios Geológicos 62(1), 135-144.

Hauptvogel D.W., Passchier S., (2012): Early-Middle Miocene (17-14 $\mathrm{Ma}$ ) Antarctic ice dynamics reconstructed from the heavy mineral provenance in the AND-2A drill core, Ross Sea, Antarctica. Global and Planetary Change 82, 38-50. doi: 10.1016/j.gloplacha.2011.11.003

Hernández-Ballarín, V., Oliver, A., Peláez-Campomanes, P. (2011): Revisión de las asociaciones de mamíferos del tránsito Aragoniense medio y superior de la Cuenca de Madrid. In: A. Pérez-García, F. Gascó, J.M. Gasulla, F. Escaso, (eds.), Viajando a Mundos Pretéritos. Ayuntamiento de Morella, Morella: 173-182.

Hernández Fernández, M. (2001): Bioclimatic discriminant capacity of terrestrial mammal faunas. Global Ecology and Biogeography 10, 189-204. doi: 10.1046/j.1466-822x.2001.00218.x.

Hernández Fernández, M., Salesa, M.J., Sánchez, I.M., Morales, J. (2003): Paleoecología del género Anchitherium von Meyer, 1834 (Equidae, Perissodactyla, Mammalia) en España: evidencias a partir de las faunas de macromamíferos. Coloquios de Paleontología 1 (vol. ext), 253-280.

Hernández Fernández, M., Alberdi, M.T., Azanza, B., Montoya, P., Morales, J., Nieto, M., Peláez-Campomanes, P. (2006a): Identification problems of arid environments in the Neogene-Quaternary mammal record of Spain. Journal of Arid Environments 66, 585-608. doi:10.1016/j.jaridenv.2006.01.013.

Hernández Fernández, M., Cárdaba, J.A., Cuevas-González, J., Fesharaki, O., Salesa, M.J., Corrales, B., Domingo, L., Elez, J., López Guerrero, P., Sala-Burgos, N., Morales, J., López Martínez, N. (2006b): Los yacimientos de vertebrados del Mioceno medio de Somosaguas (Pozuelo de Alarcón, Madrid): implicaciones paleoambientales y paleoclimáticas. Estudios Geológicos 62, 266-294.

James, F.C. (1970): Geographic size variation in birds and its relationship to climate. Ecology 51, 365-390. doi: http://dx.doi. org/10.2307/1935374.

Kennett, J.P., Barker, P.F. (1990): Latest cretaceous to Cenozoic climate and oceanographic developments in the weddell sea, antarctica: an ocean-drilling perspective. In: B. Kennett (ed.), Proceedings of the Ocean Drilling Program, Scientific Results 113, College Station, Texas: 937-960. doi: 10.2973/odp.proc.sr.113.195.1990.

Larsson, L., Dybjaer, K., Rasmussen, E.S., Piasecki, S., Utescher, T., Vajda, V. (2011): Miocene climate evolution of northern Europe: A palynological investigation from Denmark. Palaeogeography, $\mathrm{Pa}$ laeoclimatology, Palaeoecology 309, 161-175. doi: 10.1016/j.palaeo.2011.05.003.

Legendre, S. (1986): Analysis of mammalian communities from the late Eocene and Oligocene of Southern France. Palaeovertebrata 16, 191 212.

Legendre, S. (1989): Les communautés de mammifères du Paléogène (Eocène supérieur et Oligocène) d'Europe occidentale: structures, milieux et évolution. Münchner Geowissenschaftliche Abhandlungen (A) 16, 1-110.

Lewis, A.R., Marchant, D.R., Ashworth, A.C., Hedenas, L., Hemming, S.R., Johnson, J.V., Leng, M.J., Machlus, M.L., Newton, A.E., Raine, J.I., Willenbring, J.K., Williams, M., Wolfe, A.P. (2008): Mid-Miocene cooling and the extinction of tundra in continental Antarctica. Proceedings of The National Academy of Sciences of The United States of America 105, 10676-10680. doi: 10.1073/pnas.0802501105.

Lewis, M. (1997): Carnivoran paleoguilds of Africa: implications for hominid food procurement strategies. Journal of human evolution 32 , 257-288. doi: 10.1006/jhev.1996.0103.

Liu, L., Eronen, J.T., Fortelius, M. (2009): Significant mid-latitude aridity in the middle Miocene of East Asia. Palaeogeography, $\mathrm{Pa}$ laeoclimatology, Palaeoecology 279, 201-206. doi:10.1016/j.palaeo.2009.05.014.

López Martínez, N. (1977): Revisión sistemática y bioestratigráfica de los Lagomorpha (Mammalia) del Terciario y Cuaternario de España. Tesis Doctoral. Universidad Complutense de Madrid, Madrid: 469 p.

Luis, A., Hernando, J.M. (2000): Los microvertebrados fósiles del Mioceno Medio de Somosaguas Sur (Pozuelo de Alarcón, Madrid, España). Coloquios de Paleontología 51, 69-86.

Mayr, E. (1956): Geographical character gradients and climatic adaptation. Evolution 10, 105-108. doi: 10.2307/2406103.

Mayr, E. (1963): Animal species and evolution. Harvard University Press. Cambridge: $797 \mathrm{p}$.

McNab, B.K. (1971): On the ecological significance of Bergmann's rule. Ecology 52, 845-854. doi: 10.2307/1936032.

McNab, B.K. (2002): Food habits, energetics, and the population biology of mammals. The American Naturalist 116, 106-124. doi: $10.1086 / 283614$.

Mein, P. (1983): Composition quantitative des faunes de mammiferes du Miocene moyen et supérieur de la región Lyonnaise. R.C.M.N.S. Interim-Coll. Mediterranean Neogene Continental Paleoenvironments and Paleoclimatic evolution, 75-79.

Meiri, S., Dayan, T. (2003): On the validity of Bergmann's rule. Journal of biogeography 30, 331-351. doi: 10.1046/j.1365-2699.2003.00837.x.

Meiri, S., Yom-Tov, Y., Geffen, E. (2007): What determines conformity to Bergmann's rule? Global Ecology and Biogeography 16, 788-794. doi: 10.1111/j.1466-8238.2007.00330.x.

Meloro, C. (2011): Locomotor adaptations in Plio-Pleistocene large carnivores from the Italian Peninsula: Palaeoecological implications. Current Zoology 57 (3), 269-283.

Meulen, A.J. van der, Bruijn, H. de (1982): The mammals from the lower Miocene of Aliveri (1sland of Evia, Greece). Part II: The Gliridae. Koninklijke Nederlandse Akademie van Wetenschappen Proceedings B 5, 485-524.

Meulen, A.J. van der, Daams, R. (1992): Evolution of Early-Middle Miocene rodent faunas in relation to long-term palaeoenvironmental changes. Palaeogeography, Palaeoclimatlogy, Palaeoecology 93, 227-253. doi: 10.1016/0031-0182(92)90099-Q.

Montes, M., Beamud, B., Garcés, M., Calvo, J.P. (2006): Magnetoestratigrafía de las Unidades Inferior e Intermedia del Mioceno de la Cuenca de Madrid. Revista de la Sociedad Geológica de España 19, 281-298.

Montuire, S. (1999): Mammalian faunas as indicators of environmental and climatic changes in Spain during the Pliocene-Quaternary Transition. Quaternary Research 52, 129-137. doi: 10.1006/qres.1999.2041.

Moreno Bofarull A., Arias Royo, A., Hernández Fernández, M., OrtizJaureguizar, E., Morales, J. (2008): Influence of continental history on the ecological specialization and macroevolutionary processes in the mammalian assemblage of South America: differences between small and large mammals. BMC Evolutionary Biology 8, 97. doi: 10.1186/1471-2148-8-97.

Nieto, M., Rodríguez, J. (2003): Inferencia paleoecológica en mamíferos cenozoicos: limitaciones metodológicas. Coloquios de Paleontología $1,459-474$.

Palombo, M.R., Giovinazzo, C. (2006): What do cenograms tell us about mammalian palaeoecology? The example of Plio-Pleistocene Italian faunas. Late Neogene and Quaternary Biodiversity and Evolution: Regional Developments and Interregional Correlations, Vol 1. Senckenbergische Naturforschende Gesellschaft 256, 215-235.

Peláez-Campomanes, P., Morales, J., Álvarez Sierra, M.A., Azanza, B., Fraile, S., García Paredes, I., Hernández Fernández, M., Herráez, E., Nieto, M., Pérez, B., Quiralte, V., Salesa, M.J., Sánchez, I.M., Soria, D. (2003): Updated biochronology of the Miocene mammal faunas from the Madrid basin (Spain). Deinsea 10, 431-441. 
Perales, R., Serrano, H., García Yelo, B.A., Hernández Fernández, M. (2009): Inferencias paleoambientales del Mioceno medio de Somosaguas (Pozuelo de Alarcón, Madrid) basadas en la estructura de tamaños corporales de su fauna de mamíferos. Paleolusitana 1, 317-325.

Pickford, M., Morales, J. (1994): Biostratigraphy and Paleobiogeography of East-Africa and the Iberian Peninsula. Palaeogeography Palaeoclimatology Palaeoecology 112, 297-322. doi: 10.1016/00310182(94)90078-7.

Robertshaw, D., Taylor, C.R. (1969): A comparison of sweat gland activity in eight species of East African bovids. The Journal of Physiology 203, 135-143.

Rodríguez, J. (1999): Use of cenograms in mammalian palaeoecology. A critical review. Lethaia 32, 331-347. doi: 10.1111/j.1502-3931.1999. tb00551.x.

Rodríguez, J. (2001): Structure de la communauté de mammifères pléistocènes de Gran Dolina (Sierra de Atapuerca, Burgos, Espagne). L'Anthropologie 105, 131-157. doi: http://dx.doi.org/10.1016/S00035521(01)80010-8

Salesa, M.J., Sánchez, I.M., Morales, J. (2001): Los cambios ambientales y la evolución de los Anchitheriinae (Perissodactyla; Equidae) durante el Mioceno en España. Publicaciones del Seminario de Paleontología de Zaragoza 5, 457-463.

Samuels, J., Van Valkenburgh, B. (2009): Craniodental adaptations for digging in extinct burrowing beavers. Journal of Vertebrate Paleontology 29, 254-268.

Sánchez, I.M. (2000): Chalicotheriidae. In: J. Morales (coord.), Patrimonio paleontológico de la Comunidad de Madrid. Consejería de Educación de la Comunidad de Madrid, Madrid: 277-278.

Sánchez-Chillón, B., Cerdeño, E. (2000): Los rinocerontes fósiles de la Comunidad de Madrid. In: J. Morales (coord.), Patrimonio paleontológico de la Comunidad de Madrid. Consejería de Educación de la Comunidad de Madrid, Madrid: 270-274.

Scholander, P.F. (1954): Evolution of Climatic Adaptation in Homeotherms. Evolution 9, 15-26.

Sesé, C., López, N., Herráez, E. (1985): Micromamíferos (Insectivoros, Roedores y Lagomorfos) de la provincia de Madrid. In: M.T. Alberdi (ed.), Geología y Paleontología del Terciario continental de la provincia de Madrid. Museo Nacional de Ciencias Naturales, Madrid: 29-39.

Shepherd, U.L. (1998): A comparison of species diversity and morphological diversity across the North American latitudinal gradient. Journal of Biogeography 25, 19-29. doi: 10.1046/j.13652699.1998.251172.x

Shevenell, A.E., Kennett, J.P., Lea, D.W. (2004): Middle Miocene Southern Ocean Cooling and Antarctic Cryosphere Expansion. Science 305, 1766-1770. doi: 10.1126/science.1100061.

Smith, F.A., Lyons, S.K., Ernest, S.K.M., Jones, K.E., Kaufman, D.M., Dayan, T., Marquet, P.A., Brown, J.H., Haskel, J.P. (2003): Body mass of late Quaternary mammals. Ecology 84, 3403-3403. doi: $10.1890 / 02-9003$
Soria, D., Amezua, L., Daams, R., Fraile, S., Herráez, E., Morales, J., Nieto, M., Pélaez-Campomanes, P., Salesa, M.J., Sánchez, I.M. (2000): Faunas del Mioceno. In: J.Morales (coord.), Patrimonio paleontológico de la Comunidad de Madrid. Consejería de Educación de la Comunidad de Madrid, Madrid: 110-129.

Storer, J.E. (2003): Environments of Pleistocene Beringia: Analysis of faunal composition using cenograms. Deinsea 9, 405-413

Tougard, C., Montuire, S. (2006): Pleistocene paleoenvironmental reconstructions and mammalian evolution in South-East Asia: focus on fossil faunas from Thailand. Quaternary Science Reviews 25, 126141. doi: 10.1016/j.quascirev.2005.04.010.

Travouillon, K.J., Legendre, S. (2009): Using cenograms to investigate gaps in mammalian body mass distributions in Australian mammals. Palaeogeography Palaeoclimatology Palaeoecology 272, 69-84. doi: 10.1016/j.palaeo.2008.11.009.

Travouillon, K.J., Legendre, S., Archer, M., Hand, S.J. (2009): Palaeoecological analyses of Riversleigh's Oligo-Miocene sites: Implications for Oligo-Miocene climate change in Australia. Palaeogeography Palaeoclimatology Palaeoecology 276, 24-37. doi: 10.1016/j. palaeo.2009.02.025.

Valverde, J.A. (1964): Remarque sur la structure et l'évolution des communautés de vertébrés terrestres. I. Structure d'une communauté . II. Rapport entre prédateurs et proies. Terre et Vie 111, 121-154.

Valverde, J.A. (1967): Estructura de una comunidad de vertebrados terrestres. Monografías de la Estación Biológica de Doñana: 219 p.

Vrba, E.S. (1992): Mammals as a key to evolutionary theory. Journal of Mammalogy 73, 1-28. doi: 10.2307/1381862.

Walter, H. (1970): Vegetationszonen und Klima. Eugen Ulmer, Stuttgart: $245 \mathrm{p}$.

Weerd, A., Daams, R. (1978): Quantitative composition of rodent faunas in the Spanish Neogene and paleoecological implications. Proceedings Koninklijke Nederlandse Akademie Van Wetenschappen, Series $B$ 81, 448-473.

Wigginton, J.D., Dobson, F.S. (1999): Environmental influences on geographic variation in body size of western bobcats. Canadian Journal of Zoology-Revue Canadienne De Zoologie 77, 802-813. doi: 10.1139/cjz-77-5-802.

Wilson, D.E., Reeder, D.M. (1993): Mammal species of the World; A taxonomic and geographic reference. Smithsonian Institution Press, Washington: $1312 \mathrm{p}$.

Yom-Tov, Y., Geffen, E. (2006): Geographic variation in body size: the effects of ambient temperature and precipitation. Oecologia 148, $213-$ 218. doi: 10.1007/s00442-006-0364-9.

Zachos, J., Pagani, M., Sloan, L., Thomas, E., Billups, K. (2001): Trends, Rhythms, and aberrations in Global Climate 65 Ma to Present. Science 292, 686-693. doi: 10.1126/science.1059412.

Zhou, Y-B., Newman, C., Xu, W-T., Buesching, C.D., Zalewski, A., Kaneko, Y., Macdonald, D.W., Xie, Z-Q. (2011): Biogeographical variation in the diet of Holarctic martens (genus Martes, Mammalia: Carnivora: Mustelidae): adaptive foraging in generalists. Journal of Biogeography 38,137-147. doi: 10.1111/j.1365-2699.2010.02396.x. 